\title{
Comparing 2011 General Election and 2014 Presidency Election in Turkey with Regard to Political Marketing
}

\author{
Hakan Yaş \\ Trakya University Havsa Vocational School, \\ Hakan Okursoy Campus 22500 Havsa / Edirne / Turkey \\ hakanyas@trakya.edu.tr \\ Yasin Usta \\ Trakya University Havsa Vocational School, \\ Hakan Okursoy Campus 22500 Havsa / Edirne / Turkey \\ yasinusta@trakya.edu.tr \\ Sedef Zeyrekli Yaş \\ Trakya University Havsa Vocational School, Hakan Okursoy \\ Campus 22500 Havsa / Edirne / Turkey \\ sedefyas@trakya.edu.tr
}

\section{Doi:10.5901/mjss.2015.v6n2s5p139}

\section{Abstract}

\begin{abstract}
Leaders and political parties which are one of the products of political marketing are the political products. Social issues and the requirements that are the result of these issues determine the route map of leaders and the party programme. It is hard for a party and for a leader that do not embrace neither their grassroots nor the needers of the grassroots of other parties, to protect their position. Social media being used as a instrument of political marketing plays a crucial role in especially affecting young electorate at the present time. This instrument have been begun to be used by politicians actively in Turkey recently. Till the enact of the Law No. 5678 which made an amendment in 1982 Constitution in 2007, the President of Turkey had been elected by the votes of the parliamentarians in Turkish Grand National Assembly. As a result of the amendment in 1982 Constitution in 2007, Turkish citizens have become enable in electing the President of Turkey via referendum. From a different point of view, this amendment also, hereinafter, enables candidates to make their own propaganda in order to increase their votes. In this paper, 2014 Presidency Election in Turkey in which there were three candidates Recep Tayyip ERDOĞAN, Ekmeleddin Mehmet IHSANOĞLU and Selahattin DEMIRTAŞ, is considered in terms of using social media. The aim of the paper is to present the differences of the propaganda instruments of the candidates that they used in election process, and how these instruments affected the results of the elections. It is also sought that how the usage of social media and number of followers affect the results of the elections.
\end{abstract}

Keywords: Leader, Propaganda, Elections, Political Marketing, Social Media

\section{Introduction}

Although the political sciences and marketing sciences are apart areas from each other, both areas benefit from certain techniques such as target group or market, the techniques related to target group or market, picking and fragmentation of target group or market, and of which the elements of marketing mix could be used. Since for years in west of the world but yet the recent years in developing countries, it is beholden that marketing instruments have begun to be run in political campaigns as an instrument of propaganda being conducted by political candidates.

The concept of 'marketing' can be defined in several ways. Some of the scholars define the concept as "an exchange operation towards to meeting basic needs and desires of people" ... "to give some valuable things (commodity, facility or idea) to the opposite side in order to meet their each own needs between two or more sides, and to gain other valuable things (money, receivable, loan etc. )" (Mucuk, 1999: 3), whereas some defines it as "...the whole activities managing the products and services from producer to customer in order to satisfy customers and -at the same time- to reach the goals of company..." (Mc Carty, 1975: 19). 
Prior to presenting the definition of political marketing, making the definition of 'politics' is crucial. Politics can be defined as "the science of behaviours taking a role in the formation of institutions related to political authority and in their operating" and it is asserted that the politics is constituted to respond a certain requirement of all structures and of all institutions in a society (Kışlalı, 1987: 4-14). In this perspective, politics is -itself- such an instrument by which the social needs are expected to be met. Supporting this assessment, political marketing is defined as "all kinds of activities regarding promoting and introducing people -who are candidate to meet voters needs and desires-, or parties and their programmes to voters" (Özkan, 2004: 21). In political marketing, thus, leaders of political parties, parlamentarians, mayors and such people, and political parties, political propagandas and similar activities can be deemed as political products. Companies, however, use the marketing activity to create a competition advantage. As for in companies, political parties, leaders and programmes are also in a competition. In order to affect floating votes, political parties and leaders conduct their campaigns intensively via marketing activities (Okumuş, 2007: 156).

Some scholars simulate arguments of politics and arguments of marketing as the following (Divanoğlu, 2008: 106):

\begin{tabular}{|l|c|}
\hline \multicolumn{1}{|c|}{ Arguments of politics } & Argument of marketing \\
\hline Leader, party programme and candidates & Product \\
\hline Going to polls, voting, membership fees, grants, subsidies & Price \\
\hline $\begin{array}{l}\text { Mass communication devices, volunteer or paid labor, provincial and subprovincial } \\
\text { organizations, social activities and meetings held }\end{array}$ & Distribution \\
\hline $\begin{array}{l}\text { Advertisement, public relations, personal propaganda, publicity, newsworthy } \\
\text { programmes, and vote-rising other activities }\end{array}$ & Promoting \\
\hline
\end{tabular}

The differencies between commercial and political marketing are customer-wise manner - citizen-wise manner (the description of need, the description of target group, differentiated goods and services, strategies of superiorities), customer or social satisfaction - voters' satisfaction, integrated market - integrated marketing (Üste et al. , 2007: 216).

The political parties whose organizational culture is based on volunteerism achieve, recently, their runnings by the help of liaising with political consultancy companies without leaving volunteerism. These companies have integrated the elements of marketing mix into the political process and thus the concept of political marketing has become evident. While determining the place of the person in the political life, political consultancy companies researches initially to what extent the society contributes to the manner and behaviours of the person and with which processes, and to what extent a person has a freedom of action and election.

Political marketing has three customer group and these are "the ones would be member of parties, partisans and sympathizers of parties, the ones who have no other option though being not a partisan" (Limanlılar, 1991: 35). Political marketing, here, should call out these three different groups. The two aims of the political marketing are to peg the ideas of party members, potential members and voting people, and to change the ideas of voters not voting the party. Some of the aims of the party and its leader, however, should be to intensify the positive manner of the members of, the partisans of and the voters of party, to change the manner of floating votes on behalf of party, and to change manner of people from negative to -at least- floating. At this point, the main event is not the injustice in or among the level of income but the disparities between the level of income and their expectations (Kışlalı, 1987: 67). Political leaders are successful to the extent that they could respond these expectations. The leader should be able to use his characteristics of selfreliance, steady character, honesty, vigor, creative intelligence, common sense and understanding (Yıldırım, 2011: 882).

The method taking party or leader to success is propaganda which is an instrument of political marketing. The definition of propaganda made by several scholars. Qualter's definition on propaganda is "the deliberate attempt by the few to influence the attitudes and behavior of the many by the manipulation of symbolic communication" (Qualter, 1985: 124). Domenach explains it as "an undertaking of attracting the view and behavior of society so as to provide to internalize a certain view or behavior of people" (Domenach, 2003: 17). "The intentional control, manipulation and communication of information and imagery in order to achieve certain political objectives" is another definition of propaganda (Rutherford, 2000: 279)

Not completely denying the usage of internet or similar techniques, among some scholars there seems to be a consensus that it cannot replace face-to-face communication or etc (Johansen, 2012: 92). Some scholars, also, assert that with the arrival of new media such as internet, web TV or e-mail, the distribution function of political marketing will increase in complexity (Henneberg, 2002: 119). Similarly, Jackson infers from his research, in which he studies the members of parliament in United Kingdom in 2002, that email so far has not stimulated a relationship marketing approach (Jackson, 2005: 105). In addition to these studies, some directly work on new social media instruments. In their study, Bode \& Dalyrmple suggested that Twitter contains a unique audience for political elites to target. These users extremely 
interested in politics, very likely to turn out at the polls, and wealthy enough to contribute to campaigns. The important finding of this study is that as politicians, pundits, and politically interested citizens continue to turn to Twitter as a source of information and a form of political expression (Bode \& Dalyrmple, 2014: 22). Miller studied both Twitter and Facebook and called them new media in modern political campaigns. In his research he concludes that what makes new media attractive is cheapness, opportunity to enhance the images of candidates. But the shortcoming of this new media is its failure to reach a vast majority of voters (Miller, 2013: 342). Towner and Dulio, other scholars using the term new media for Twitter and Facebook -and also Youtube-, find new media likely "a futile proposition" and suggest that the rapid changes in new media require scholars to update the design and direction of future research (Towner and Dulio, 2012: 112).

In the light of all considerations above, in this paper it is, in brief, endeavoured to make an assessment of 2014 Presidency Election in Turkey, within the scope of Twitter and Facebook which are some of the instruments of new social media. The aim of the paper is to suggest the differency of the propoaganda instruments used by three candidates competing in 2014 Presidency Election, Recep Tayyip ERDOĞAN, Ekmeleddin Mehmet IHSANOĞLU and Selahattin DEMIRTAŞ, and how these instruments affected the votes. Besides, it is also studied how the usage of social media and the number of followers affect the votes. The instruments of propaganda and usage of social media in number are left out of the scope for 2011 General Election as social media was not used effectively by the leaders in the Election. Therefore, a comparison between the two elections is done and a determination of the power of effect of the social media is tried to be done by through assuming the effects of other factors as equal.

Thus, the main assumption of the paper is set as "political marketing has a positive affect on votes". In this regard either political marketing techniques (social media and meetings) used by the candidates in the running process or the 2014 Presidency Election itself are also considered. In this context, the paper seeks to answer the following key questions:

- What are the differencies between the candidates in terms of methods and instruments used by them?

- How did these methods and instruments affect the votes?

- Did the candidates increase their vote rate in 2014 Presidency Electon if compared with 2011 General Election?

\section{Analysis}

\subsection{Comparing the Candidates in Terms of Their Usage of Social Media}

Social media and social communication are new propaganda instruments drawing its strength from people, carrying the people from passive to active following, consisting of people from all strata, to which politicans appeal for help in their campaigns, and about what they -on occasion- complain. The users who don't read or watch although prefering journals, magazines and television can share their thoughts in social media. The conventional methods of propaganda which can not respond to instant developments countrywide, such as visiting electoral area, are going useless, but one sentence shared in social media can be followed from all these areas. As stated in the previous chapter, in this paper Facebook and Twitter are regarded as social media or new media instruments, and analyzed.

Turkey is the $6^{\text {th }}$ in the World ranking while it is $1^{\text {st }}$ in Europe ranking in terms of the number of users of Facebook, with 31. 247. 120 users according to 2012 data which indicates that over the $40 \%$ of population of Turkey use Facebook. If this data is compared with the number of users of internet, it indicates that each nine of ten individuals has a Facebook account. At the $18-24$ age range, there are over 10 million users with a share of approximately $34 \%$ of total, whereas at the 25 - 34 range 28\% and $35-44$ range 12\% (Sabah, 2014). The number of users of Twitter, however, reached a number over 11 million by the year 2014, which means that each 4 of 10 individuals using internet use Twitter.

These data indicate that the number of using internet, Facebook and Twitter is growing rapidly in Turkey. Following and taking into consideration this reality, it is obvious that the candidates of 2014 Turkish Presidency Election have to prefer to use the social media actively.

Selahattin DEMIRTAŞ had rather use his Twitter account actively than his Facebook account. The number of his followers in Facebook is 1. 197. 739. The most of his followers are situated in İstanbul and he is followed mostly by the age range $18-24$. He had 106 sharing in total, 17 of which are short-film, 82 of which are messages and photos taken in campaign running, and 7 of which are advertisements. Although he has two Twitter accounts, he had rather use @DegisiminAdayi account and run his campaign. In this account which has over 15. 000 followers, he released 1. 530 sharing, 172 of which are short film and the rest is 1.222 messages. In addition to these accounts, he has also another web page www. selahattindemirtas. net over which he presented his next events. According to data released on his web 
page, he raised totally 1. 213. $000 \mathrm{TL}$ donation from 7. 119 donors. ${ }^{1}$ He spent 1. $095.000 \mathrm{TL}$ of the total amount for promotion materials, transportation and audio system. (http: //www. selahattindemirtas. net/, 2014). His site was created not only in Turkish but also in English and Kurdish.

Ekmeleddin Mehmet IHSANOĞLU used his Facebook account actively which was created in 2014, 24th of June and the number of his followers is 361. 097. The most of his followers are situated in İstanbul and he is followed mostly by the age range $18-24$. He had 134 sharing in total, 50 of which are short-film, 69 of which are messages and photos taken in campaign running, and 15 of which are advertisements. In his Twitter account "@profdrihsanoglu", he has 344. 551 followers and he released 357 sharing in total, 15 of which are short film, 311 of which are messages and 21 of which are advertisements. If his Facebook account is compared to his Twitter account, it is inferred that he used his Twitter account actively rather than Facebook in order to share message, and that the number of followers in his Twitter account is more than the number in Facebook. In addition to these accounts, he has also another web page ihsanoglu. com over which he presented his next events and made a call for raise donation. He raised totally 8. 500. 000 TL donation from an undeclared number of donors (http: //www. sozcu. com. tr/2014/gundem/iste-erdogana-yapilan-secim-bagisi-573957/). His web page was created only in Turkish Language.

Recep Tayyip ERDOĞAN has 6. 390. 605 followers in Facebook. He has the most followers in İstanbul, and most followed by the age range $18-24$. He had 98 sharing in total, 53 of which are message, 23 of which are campaign photos and 12 of which are advertisement. In his Twitter account "@RT_Erdogan", he has 4. 625. 669 followers. In his account from which he released 180 sharing, he had 6 short films, 17 advertisements and 157 messages. It is seen that he used his Twitter account more active rather than Facebook. Recep Tayyip ERDOĞAN who presented his running events from his personal web page www. rte. com. tr, raised 55. 260. 778 TL donation from 1. 350.796 donors (http: I/www. trtturk. com/haber/cumhurbaskani-adaylari-ne-kadar-bagis-topladi. html, 27. 08. 2014; http: //www. rte. com. tr/ 16. 08. 2014).

Candidates reached their voters also from Instagram and Youtube, but this lies outside the scope of the paper.

An increase occurred in Recep Tayyip ERDOGAN's "@RT_Erdogan" Twitter account by the start of the election campaign and the number of followers increased by 98. 606 followers. However, his Facebook account increased in number with 97. 506 followers. Selahattin DEMIRTAŞ's "@DegisiminAdayi" Twitter account followed by 15. 664 new followers, whereas his Facebook account followed by 21. 406 new followers. The effect of start of election was more in Ekmeleddin Mehmet IHSANOĞLU's social media accounts than in other candidates. Thanks to the election, he created new accounts in Twitter and Facebook. His Facebook account and Twitter account were followed by 361.097 and 344. 551 new followers respectively. The ratio of followers commented on candidates are as follows: on Recep Tayyip ERDOĞAN 49,60\%, on Ekmeleddin Mehmet IHSANOĞLU 39,82\% and on Selahattin DEMIRTAŞ 10,28\%.

Table 1 indicates the change in number of followers of candidates in Twitter from $9^{\text {th }}$ July to $8^{\text {th }}$ August.

Table 1: The Number of Twitter Followers of Candidates Between The Days of $9^{\text {th }}$ July- $8^{\text {th }}$ August 2014

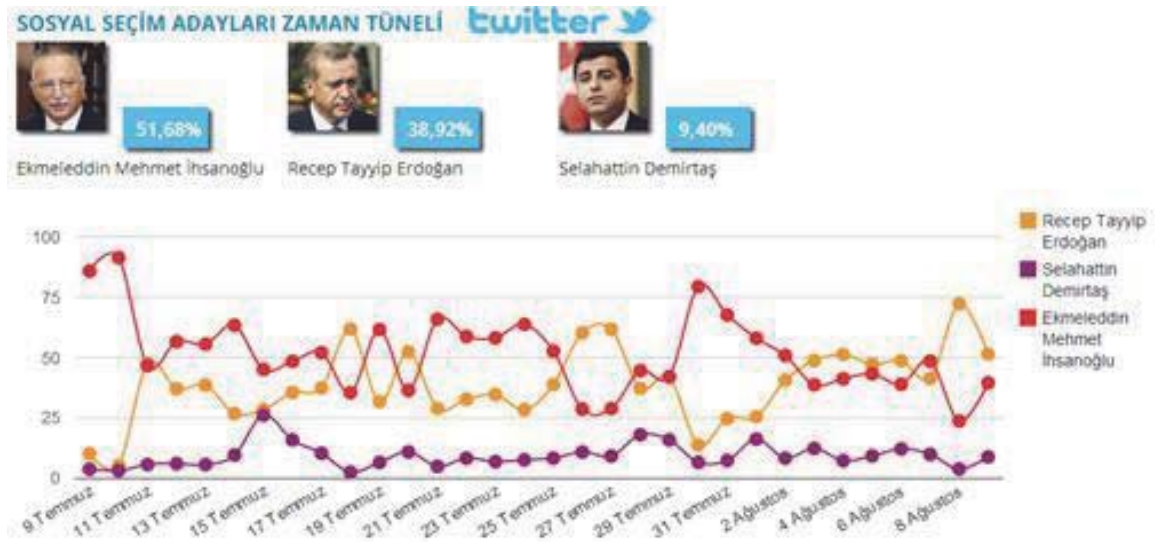

Resource: http: //www. haberturk. com/secim/secim2014/cumhurbaskanligi-secimi, 13. 08. 2014

${ }^{1}$ According to Law No. 6271, candidates can raise donation from individuals or companies except individuals that are non-citizen of Turkey and foreign companies. 
Table 2: The Provinces in Which the Candidates Are the First

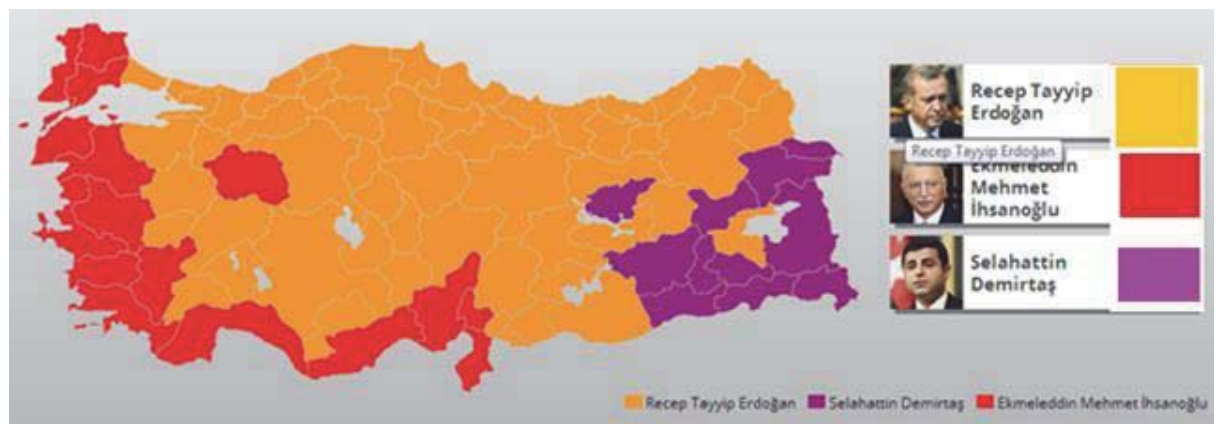

Table 3: The Candidates' Vote Numbers, The Comparison of Provinces and Metropolitans

\begin{tabular}{|c|c|c|c|c|}
\hline Candidate & The Number of Metropolitan Voted & The Number of Province Voted & Vote Rate & $\begin{array}{c}\text { The Vote Number of } \\
\text { President Elections }\end{array}$ \\
\hline Recep Tayyip Erdoğan & 15 & 39 & 51,79 & 21.000 .143 \\
\hline Ekmeleddin Ihsanoğlu & 12 & 4 & 38,44 & 15.587 .720 \\
\hline Selahattin Demirtaş & 3 & 8 & 9,76 & 3.958 .048 \\
\hline
\end{tabular}

\subsection{Comparing the Candidates in Terms of Their Meetings Held}

Selahattin DEMIRTAŞ started his campaign running from İstanbul in $15^{\text {th }}$ July and met his voters by visiting Kocaeli and Bursa in $16^{\text {th }}$ July, in $18^{\text {th }}$ July Basel and Paris, in $22^{\text {nd }}$ July İstanbul, in $23^{\text {rd }}$ July Muş, in $24^{\text {th }}$ July Bitlis, Siirt and Tekirdağ, in $25^{\text {th }}$ July Antalya, in $26^{\text {th }}$ July Aydın, in $27^{\text {th }}$ July Manisa, in $28^{\text {th }}$ July Şirnak, in $29^{\text {th }}$ July Hakkari, in $30^{\text {th }}$ July İstanbul, in $31^{\text {st }}$ July Hatay, in $1^{\text {st }}$ August Mersin, Şanlıurfa and Gaziantep, in $2^{\text {nd }}$ August Bingöl, Tunceli and İstanbul, in $4^{\text {th }}$ August Ağrı, in $5^{\text {th }}$ August Van, in $6^{\text {th }}$ August Diyarbakır and Adana, in $9^{\text {th }}$ August Izmir.

He gained his votes most in Şirnak, Hakkari and Diyarbakır with the ratios 83,13\%, 81,27\% and 64,10\% respectively, whereas least in Bayburt, Yozgat and Çankırı with the ratios 0,75\%,1,00\% and 1,00\% respectively. His ranking in Şirnak, Hakkari, Diyarbakır, Ağrı, Muş, Van, Siirt and Tunceli, the provinces where he visited during his running, is $1^{\text {st }}$, whereas in Bitlis, Bingöl and Şirnak is $2^{\text {nd }}$ and in other provinces is $3^{\text {rd }}$.

Table 4: Selahattin Demirtaş's Vote Density in Turkey

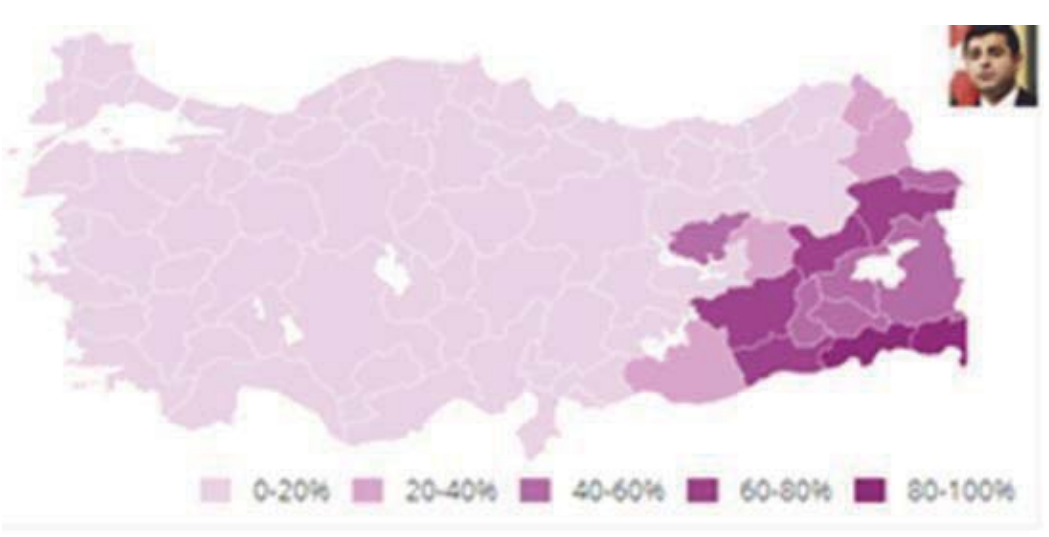


Table 5: Selahattin Demirtaş's Election Success in Provinces Run Campaign, The Comparison Analysis of President Election (2014) and General Election (2011)

\begin{tabular}{|c|c|c|c|c|c|c|c|}
\hline \multicolumn{8}{|c|}{ Selehattin Demirtaş² } \\
\hline $\begin{array}{l}\text { The Campaign Success } \\
\text { Ranking Among Provinces }\end{array}$ & Province & Vote Rate \% & His Ranking of Success & $\begin{array}{l}\text { President Election } \\
\text { Vote Count }\end{array}$ & $\begin{array}{c}2011 \text { General } \\
\text { Election Vote Count }\end{array}$ & $\begin{array}{l}\text { The Increase } \\
\text { Number of Vote }\end{array}$ & Increase Rate \% \\
\hline 1 & Şirnak & 82,94 & 1 & 158569 & 125225 & 33344 & 26,63 \\
\hline 2 & Hakkâri & 81,65 & 1 & 102342 & 94580 & 7762 & 8,21 \\
\hline 3 & Diyarbakir & 64,23 & 1 & 409681 & 340598 & 69083 & 20,28 \\
\hline 4 & Ağri & 61,54 & 1 & 121512 & 87915 & 33597 & 38,22 \\
\hline 5 & Muş & 61,24 & 1 & 105248 & 75599 & 29649 & 39,22 \\
\hline 6 & Mardin & 60,89 & 1 & 198345 & 195041 & 3304 & 1,69 \\
\hline 7 & Batman & 59,95 & 1 & 134266 & 113165 & 21101 & 18,65 \\
\hline 8 & Van & 54,49 & 1 & 222670 & 210332 & 12338 & 5,87 \\
\hline 9 & Siirt & 54,03 & 1 & 65373 & 51483 & 13890 & 26,98 \\
\hline 10 & Tunceli & 52,24 & 1 & 41613 & 10344 & 31269 & 302,29 \\
\hline 11 & Bitlis & 43,67 & 2 & 60448 & 58475 & 1973 & 3,37 \\
\hline 12 & lğdir & 42,90 & 1 & 30227 & 25388 & 4839 & 19,06 \\
\hline 13 & Kars & 32,86 & 2 & 41187 & 27561 & 13626 & 49,44 \\
\hline 14 & Bingöl & 30,54 & 2 & 37385 & 30110 & 7275 & 24,16 \\
\hline 15 & Şanliurfa & 26,20 & 2 & 173691 & 182435 & -8744 & $-4,79$ \\
\hline 16 & Ardahan & 23,07 & 3 & 11663 & 7081 & 4582 & 64,71 \\
\hline 17 & Adiyaman & 15,25 & 3 & 43626 & 19960 & 23666 & 118,57 \\
\hline 18 & Mersin & 13,42 & 3 & 122134 & 93495 & 28639 & 30,63 \\
\hline 21 & Adana & 10,62 & 3 & 114035 & 92792 & 21243 & 22,89 \\
\hline 22 & Gaziantep & 10,51 & 3 & 82659 & 44475 & 38184 & 85,85 \\
\hline 23 & Istanbul & 9,06 & 3 & 648608 & 1261938 & -613330 & $-48,60$ \\
\hline 24 & Izmir & 7,95 & 3 & 187405 & 240478 & -53073 & $-22,07$ \\
\hline 25 & Aydin & 6,94 & 3 & 41568 & 23997 & 17571 & 73,22 \\
\hline 27 & Manisa & 5,57 & 3 & 45828 & 24193 & 21635 & 89,43 \\
\hline 28 & Kocaeli & 5,47 & 3 & 48713 & 21827 & 26886 & 123,18 \\
\hline 29 & Antalya & 5,27 & 3 & 58046 & 28110 & 29936 & 106,50 \\
\hline 32 & Tekirdağ & 4,38 & 3 & 22245 & 7646 & 14599 & 190,94 \\
\hline 38 & Hatay & 3,58 & 3 & 28151 & 11778 & 16373 & 139,01 \\
\hline 44 & Balikesir & 2,82 & 3 & 21111 & 6757 & 14354 & 212,43 \\
\hline & & & & 3378349 & 3512778 & -134429 & $-3,83$ \\
\hline
\end{tabular}

Recep Tayyip ERDOĞAN started his running from Samsun in $5^{\text {th }}$ July and visited Erzurum in $6^{\text {th }}$ July, Ankara and Denizli in $8^{\text {th }}$ July, Tokat in $9^{\text {th }}$ July, Yozgat in $10^{\text {th }}$ July, Antalya in $12^{\text {th }}$ July, Şanlıurfa in $13^{\text {th }}$ July, Sakarya in $16^{\text {th }}$ July, Tekirağ in $17^{\text {th }}$ July, Bursa in $18^{\text {th }}$ July, Ordu in $19^{\text {th }}$ July, Hatay in $20^{\text {th }}$ July, Adana in $23^{\text {rd }}$ July, Mersin in $24^{\text {th }}$ July, Eskişehir, Bilecik And İstanbul in $25^{\text {th }}$ July, Diyarbakır in $26^{\text {th }}$ July, Van and Mardin in $31^{\text {st }}$ July, Kahramanmaraş and Manisa in $1^{\text {st }}$ August, Balıkesir and İzmir in $2^{\text {nd }}$ August, Ağrı, Kocaeli and İstanbul in $3^{\text {rd }}$ August, Aydın and Muğla in $6^{\text {th }}$ August, Malatya and Gaziantep in $7^{\text {th }}$ August, Kayseri and Ankara in August $8^{\text {th }}$, and Konya in $9^{\text {th }}$ August.

He gained his votes most in Bayburt, Rize and Gümüşhane with the ratios $80,24 \%, 78,90 \%$ and $75,09 \%$ respectively, whereas least in Tunceli, Şirnak and Hakkari with the ratios 14,67\%, 14,83\% and 16,63\% respectively. He did not prefer to make any running visit to the provinces where he was voted most, in contrast to his opponents who made the reverse. His ranking in Konya, Kahramanmaraş, Malatya, Sakarya, Erzurum, Şanlıurfa, Ordu, Kayseri, Samsun, Yozgat, Tokat, Gaziantep, Kocaeli, Bursa, Ankara, Bilecik, İstanbul, the provinces where he visited during his running, is $1^{\text {st }}$, whereas he is $2^{\text {nd }}$ in Balıkesir, Denizli, Manisa, Eskişehir, Hatay, Van, Antalya, Adana, Tekirdağ, Mardin, Aydın, Ağrı, Diyarbakır, İzmir, Muğla, Mersin.

2 The yellow-based rows indicates the provinces that the candidate visited during his running. 
Table 6: Recep Tayyip Erdoğan's Vote Density in Turkey

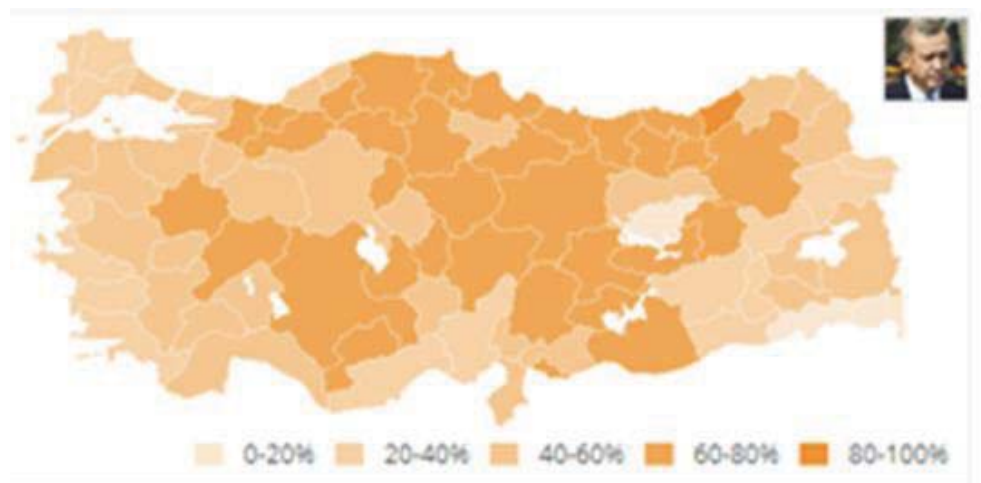

Table 7: Recep Tayyip Erdoğan's Election Success in Provinces Run Campaign, The Comparison Analysis of President Election (2014) and General Election (2011)

\begin{tabular}{|c|c|c|c|c|c|c|c|}
\hline \multicolumn{8}{|c|}{ Recep Tayyip Erdoğan ${ }^{3}$} \\
\hline $\begin{array}{l}\text { The Campaign Success } \\
\text { Ranking Among Provinces }\end{array}$ & Province & Vote Rate \% & $\begin{array}{l}\text { His Ranking of } \\
\text { Success }\end{array}$ & $\begin{array}{c}\text { President Election } \\
\text { Vote Count }\end{array}$ & $\begin{array}{c}2011 \text { General } \\
\text { Election Vote Count }\end{array}$ & $\begin{array}{c}\text { The Increase Number of } \\
\text { Vote }\end{array}$ & Increase Rate \% \\
\hline 1 & Bayburt & 80,24 & 1 & 34102 & 27201 & 6901 & 25,37 \\
\hline 2 & Rize & 78,90 & 1 & 148587 & 133987 & 14600 & 10,90 \\
\hline 3 & Gümüşhane & 75,09 & 1 & 52499 & 44993 & 7506 & 16,68 \\
\hline 4 & Konya & 74,63 & 1 & 826792 & 807073 & 19719 & 2,44 \\
\hline 5 & Aksaray & 74,00 & 1 & 136863 & 131853 & 5010 & 3,80 \\
\hline 6 & Çankiri & 73,71 & 1 & 76265 & 72437 & 3828 & 5,28 \\
\hline 8 & K. Maraş & 71,49 & 1 & 382945 & 390259 & -7314 & $-1,87$ \\
\hline 10 & Malatya & 70,29 & 1 & 285266 & 293377 & -8111 & $-2,76$ \\
\hline 15 & Sakarya & 69.08 & 1 & 349035 & 333384 & 15651 & 4,69 \\
\hline 16 & Erzurum & 68,83 & 1 & 250942 & 282436 & -31494 & $-11,15$ \\
\hline 17 & Şanliurfa & 68,63 & 1 & 454976 & 428691 & 26285 & 6,13 \\
\hline 18 & Ordu & 66,98 & 1 & 245784 & 250309 & -4525 & $-1,81$ \\
\hline 21 & Kayseri & 66,14 & 1 & 474374 & 476428 & -2054 & $-0,43$ \\
\hline 23 & Samsun & 65,88 & 1 & 447022 & 460035 & -13013 & $-2,83$ \\
\hline 25 & Yozgat & 65,85 & 1 & 155662 & 170222 & -14560 & $-8,55$ \\
\hline 33 & Tokat & 62,29 & 1 & 206764 & 201612 & 5152 & 2,56 \\
\hline 35 & Gaziantep & 60,47 & 1 & 475202 & 508653 & -33451 & $-6,58$ \\
\hline 38 & Kocaeli & 58,54 & 1 & 521248 & 502110 & 19138 & 3,81 \\
\hline 42 & Bursa & 54,88 & 1 & 848418 & 871796 & -23378 & $-2,68$ \\
\hline 48 & Ankara & 51,31 & 1 & 1405405 & 1465940 & -60535 & $-4,13$ \\
\hline 49 & Bilecik & 50,91 & 1 & 62052 & 54685 & 7367 & 13,47 \\
\hline 52 & Istanbul & 49,84 & 1 & 3566474 & 3913708 & -347234 & $-8,87$ \\
\hline 54 & Balikesir & 47,80 & 2 & 356945 & 355059 & 1886 & 0,53 \\
\hline 55 & Denizli & 47,09 & 2 & 268044 & 277951 & -9907 & $-3,56$ \\
\hline 56 & Manisa & 46,14 & 2 & 379180 & 405540 & -26360 & $-6,50$ \\
\hline 57 & Eskişehir & 45,41 & 2 & 214498 & 221355 & -6857 & $-3,10$ \\
\hline 58 & Hatay & 44,11 & 2 & 345934 & 352060 & -6126 & $-1,74$ \\
\hline 59 & Van & 42,65 & 2 & 174309 & 171012 & 3297 & 1,93 \\
\hline 63 & Antalya & 41,63 & 2 & 458271 & 460693 & -2422 & $-0,53$ \\
\hline 65 & Adana & 38,92 & 2 & 417602 & 436364 & -18762 & $-4,30$ \\
\hline 66 & Tekirdağ & 38,21 & 2 & 193739 & 182748 & 10991 & 6,01 \\
\hline 68 & Mardin & 36,62 & 2 & 119293 & 102956 & 16337 & 15,87 \\
\hline 69 & Aydin & 36,75 & 2 & 219858 & 223349 & -3491 & $-1,56$ \\
\hline 70 & Ağri & 36,46 & 2 & 72336 & 96197 & -23861 & $-24,80$ \\
\hline 72 & Diyarbakir & 33,50 & 2 & 214023 & 217602 & -3579 & $-1,64$ \\
\hline 73 & İzmir & 33,38 & 2 & 786547 & 920362 & -133815 & $-14,54$ \\
\hline 74 & Muğla & 32,26 & 2 & 164666 & 169449 & -4783 & $-2,82$ \\
\hline 76 & Mersin & 31,99 & 2 & 291092 & 309603 & -18511 & $-5,98$ \\
\hline & & & & 16083014 & 16723489 & -640475 & $-3,83$ \\
\hline
\end{tabular}

Ekmeleddin Mehmet İHSANOĞLU started his campaign by visiting, initially, Mausoleum of Atatürk and Mausoleum of Hacı Bayram Veli in Turkey. After, he went to Yozgat, his birthplace, and Nevşehir to visit Mausoleum of Hacı Bektaşi Veli. In order to run his campaign, he visited Trabzon in $4^{\text {th }}$ July, Sakarya in $5^{\text {th }}$ July, Aydın in $7^{\text {th }}$ July, İstanbul in $8^{\text {th }}, 9^{\text {th }}$, and $10^{\text {th }}$ July, Erzurum in $11^{\text {th }}$ July, Bursa in $12^{\text {th }}$ July, Edirne, Kırklareli and Tekirdağ in $13^{\text {th }}$ July, Gaziantep in $16^{\text {th }}$ July,

3 The yellow-based rows indicates the provinces that the candidate visited during his running. 
Konya in $17^{\text {th }}$ July, Kocaeli in $19^{\text {th }}$ July, Izmir in $22^{\text {nd }}$ July, İstanbul in $23^{\text {rd }}$ July, Kayseri in $24^{\text {th }}$ July, Diyarbakır in $25^{\text {th }}$ July, Antalya in $26^{\text {th }}$ July, İstanbul in $27^{\text {th }}$ and $28^{\text {th }}$ July, Sivas in $31^{\text {st }}$ July, Adana and Mersin in $1^{\text {st }}$ August, Hatay in $2^{\text {nd }}$ August, İstanbul in $3^{\text {rd }}$ August, Ankara in $4^{\text {th }}$ August, Eskişehir in $5^{\text {th }}$ August, Bilecik in $6^{\text {th }}$ August, Samsun in $7^{\text {th }}$ August, Balıkesir and Manisa in $8^{\text {th }}$ August. He had rather meet NGOs and his voters face to face than hold a meeting in contrast to his opponents, wherever he visited.

Being as a joint candidate of the two opposition parties, he gained his votes most in Kırklareli, Edirne and Muğla with the ratios $68,08 \%, 64,91 \%$ and $63,96 \%$ respectively, whereas least in Batman, Şirnak and Hakkari with the ratios $1,98 \%, 2,04 \%$ and $2,11 \%$ respectively. Diyarbakır is the only province where he could not gain votes. His ranking in Kırklareli, Edirne, Muğla, İzmir, Tekirdağ, Aydın, Mersin, Antalya, Eskişehir, Hatay, Adana, Balıkesir, Manisa is $1^{\text {st }}$, whereas in Bilecik, Ankara, Kocaeli, Nevşehir, Yozgat, Samsun, Kayseri, Gaziantep, Sivas, Trabzon, Sakarya, Konya and Samsun he is $2^{\text {nd }}$. He could not stop the decrease of his votes although he visited the provinces from where he gained his votes most, with respect to his opponents.

Table 8: Ekmeleddin İhsanoğlu's Vote Density in Turkey

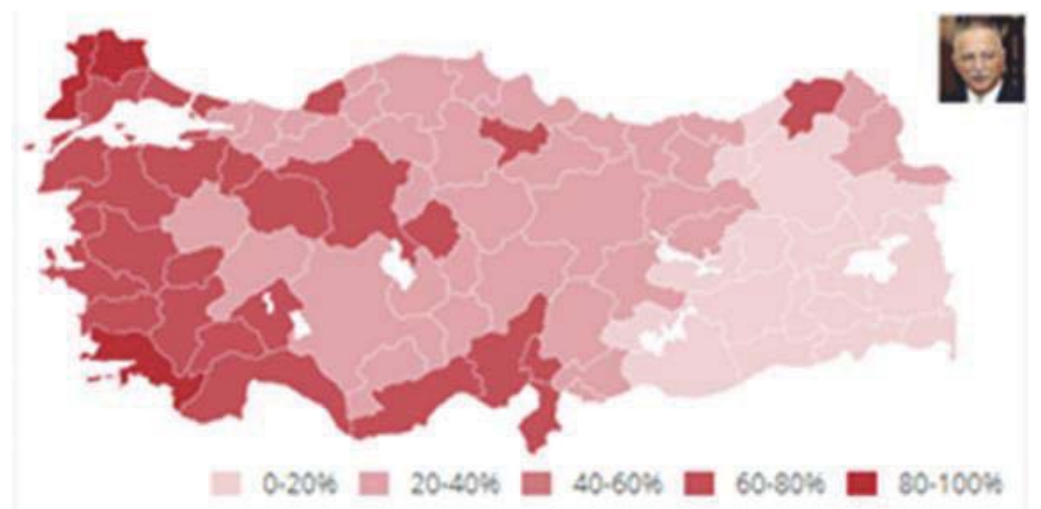

Table 9: Ekmeleddin İhsanoğlu's Election Success in Provinces Run Campaign, The Comparison Analysis of President Election (2014) and General Election (2011)

\begin{tabular}{|c|c|c|c|c|c|c|c|c|}
\hline \multicolumn{9}{|c|}{ Ekmeleddin Mehmet Ihsanoğlu 4} \\
\hline $\begin{array}{l}\text { The Campaign } \\
\text { Success Ranking } \\
\text { Among Provinces }\end{array}$ & Province & $\begin{array}{l}\text { Vote Rate } \\
\%\end{array}$ & $\begin{array}{c}\text { His Ranking of } \\
\text { Success }\end{array}$ & $\begin{array}{c}\text { President } \\
\text { Election Vote } \\
\text { Count }\end{array}$ & $\begin{array}{l}2011 \text { General Election } \\
\text { Vote Count }\end{array}$ & $\begin{array}{c}\text { The Increase } \\
\text { Number of Vote }\end{array}$ & $\begin{array}{l}\text { Increase } \\
\text { Rate } \%\end{array}$ & $\begin{array}{c}\text { The Campaign Success Ranking Among } \\
\text { Provinces }\end{array}$ \\
\hline 1 & Kirklareli & 67,98 & 1 & 38,31 & 144488 & 160359 & -15871 & $-9,90$ \\
\hline 2 & Edirne & 64,94 & 1 & 32,75 & 156912 & 176233 & -19321 & $-10,96$ \\
\hline 3 & Muğla & 63,64 & 1 & 31,42 & 324662 & 336596 & -11934 & $-3,55$ \\
\hline 4 & İmir & 58,65 & 1 & 25,38 & 1382320 & 1421484 & -39164 & $-2,76$ \\
\hline 5 & Tekirdağ & 57,19 & 1 & 18,99 & 290959 & 305004 & -14045 & $-4,60$ \\
\hline 6 & Aydin & 56,31 & 1 & 19,55 & 336768 & 372024 & -35256 & $-9,48$ \\
\hline 8 & Mersin & 54,49 & 1 & 22,45 & 496576 & 552979 & -56403 & $-10,20$ \\
\hline 9 & Antalya & 53,06 & 1 & 11,44 & 584390 & 660731 & -76341 & $-11,55$ \\
\hline 10 & Eskişehir & 51,94 & 1 & 6,52 & 245453 & 264844 & -19391 & $-7,32$ \\
\hline 11 & Hatay & 51,86 & 1 & 7,33 & 410105 & 416119 & -6014 & $-1,45$ \\
\hline 12 & Adana & 50,43 & 1 & 11,45 & 541300 & 617175 & -75875 & $-12,29$ \\
\hline 14 & Balikesir & 49,62 & 1 & 1,50 & 368593 & 383325 & -14732 & $-3,84$ \\
\hline 16 & Manisa & 48,26 & 1 & 2,11 & 396755 & 418627 & -21872 & $-5,22$ \\
\hline 18 & Bilecik & 46,05 & 2 & $-4,85$ & 56132 & 69263 & -13131 & $-18,96$ \\
\hline 19 & Ankara & 45,01 & 2 & $-6,15$ & 1238886 & 1428950 & -190064 & $-13,30$ \\
\hline 35 & Kocaeli & 35,89 & 2 & $-22,71$ & 320396 & 366585 & \begin{tabular}{|l|}
-46189 \\
\end{tabular} & $-12,60$ \\
\hline 39 & Nevşehir & 34,18 & 2 & $-30,24$ & 55268 & 62299 & -7031 & $-11,29$ \\
\hline 42 & Yozgat & 33,21 & 2 & $-32,57$ & 78514 & 80353 & -1839 & $-2,29$ \\
\hline 43 & Samsun & 32,78 & 2 & $-33,10$ & 222587 & 264582 & -41995 & $-15,87$ \\
\hline 48 & Kayseri & 32,00 & 2 & $-34,16$ & 229627 & 239131 & -9504 & $-3,97$ \\
\hline 53 & Gaziantep & 29,00 & 2 & $-31,46$ & 227967 & 253787 & -25820 & $-10,17$ \\
\hline 54 & Sivas & 28,80 & 2 & $-41,19$ & 101527 & 108539 & -7012 & $-6,46$ \\
\hline 55 & Trabzon & 28,72 & 2 & $-41,39$ & 112274 & 161215 & -48941 & $-30,36$ \\
\hline 56 & Sakarya & 28,64 & 2 & $-40,45$ & 144756 & 177841 & -33085 & $-18,60$ \\
\hline 64 & Konya & 22,33 & 2 & $-52,29$ & 247340 & 296670 & -49330 & $-16,63$ \\
\hline 68 & Erzurum & 18,20 & 2 & $-50,72$ & 66115 & 81964 & \begin{tabular}{|l|}
-15849 \\
\end{tabular} & $-19,34$ \\
\hline & & & & & 8780670 & 9676679 & -896009 & $-9,26$ \\
\hline
\end{tabular}

${ }^{4}$ The yellow-based rows indicates the provinces that the candidate visited during his running. 
To sum up, Recep Tayyip ERDOĞAN finished the 'rivalry' first in 56 of the 81 provinces, whereas second in 23 and third in 2. Selahattin DEMIRTAS had finished first in 10, second in 5 and third in 66 of the 81 provinces. Ekmeleddin Mehmet IHSANOĞLU was first in 15 provinces, 12 of where are the provinces he visited in his campaign. He was second in 53 provinces, 13 of where are the provinces he visited. He, lastly, was third in the rest of the 13 provinces.

\section{Conclusions}

When the total number of followers of the candidates in social media are compared, it is clear that Ekmeleddin Mehmet IHSANOĞLU reached a number of followers more than his opponents. He, however, couldn't increase his votes as much as his opponents. Another weakness of him is that his personal web page was created only in Turkish. Though it is a positive distinction from the two other opponents that he preferred a face to face communication, he caused a decline in the votes of the two parties -even in the provinces he ranked in first- which stated him as a joint candidate, when compared to 2011 General Elections.

In spite of his negative opinion against Facebook and Twitter before his candidateship of Presidency, he is the first in terms of having followers in these social media instruments. He did not have any visit to five cities where he ranked first, except Konya. His votes, however, declined slightly in Central Anatolia, Aegean, East and Southeast Regions. His votes, also, declined 3,83\% by random provinces, likewise there is a ratio of $4,16 \%$ decline in the provinces where had visits.

Selahattin DEMIRTAŞ is the candidate who had most sharing in social media instruments with a ratio that is five times more his opponents. He increased his votes in 2014 compared to 2011 in where he visited, but decreased in Şanlıurfa, İstanbul and İzmir although he visited. Although he decreased his votes in İstanbul and İzmir with the ratios $48 \%$ and $22 \%$, respectively, in comparison to 2011 General Elections, he increased his votes in where he visited during his campaign. However, the decline in his votes in İstanbul and İzmir shows that there is an overall decline in both random and other provinces he visited, by affecting the average with a ratio of 3,83\%.

In conclusion, it can be suggested there is no explicit causality between the number of followers in social media and the results of 2014 Presidency Elections in Turkey. It is, however, remarkable that there is a close relationship between the comment or tweet shared by followers and the votes that the candidates gained in 2014 Presidency Elections. Consequently, it is possible to deduce that political marketing through social media has positive affect on 2014 Presidency Elections in Turkey.

\section{References}

Bode, L. \& Dalrymple, Kajsa E. (2014). Politics in 140 Characters or Less: Campaign Communication, Network Interaction, and Political Participation on Twitter. Journal of Political Marketing, DOI: 10. 1080/15377857. 2014. 959686 (accepted but not published paper)

Divanoğlu S. U. (2008). Seçim Kampanyalarında Siyasal Pazarlama Karması Elemanlarının Yeri ve Önemi, Niğde Üniversitesi Iktisadi ve Idari Bilimler Fakültesi Dergisi, Cilt: 1, Sayı: 2, 105-118.

Domenach J M. (2003). Politika ve Propaganda, İstanbul: Varlık Yayınları.

Henneberg, Stephan C. M. (2002). Understanding political marketing. In Henneberg, Stephan C. M. \& O'Shaughnessy, Nicholas J. (Eds.) , The Idea of Political Marketing (pp. 93 - 158). Westport CT, United States of America: Praeger Publishers.

Jackson, N. (2005). Vote Winner or a Nuisance: Email and Elected Politicians' Relationship with Their Constituents. Current Issues in Political Marketing, (eds: Walter W. Wymer, Jr. , and Jennifer LeesMarshment) Best Business Books, an imprint of The Haworth Press, Inc. , 91-108.

Johansen, Helene, P. M. (2012). Relational Political Marketing in Party-centred Democracies: Because We Deserve It. UK: MPG Books Group.

Kostik Z. (2003): "TSK Asker Hastanesi Yöneticilerinin önderlik Davranışlarının Tespiti ve Sergilenen Önderlik Davranışları ile Kurum Performansları Arasındaki Ilişkinin Analizi”, Ankara: Gülhane Askeri Tıp Akademisi, Yayınlanmamış Doktora Tezi, Akt. Yıldırım N. (2011): "Eğitim Gönüllüsü Kanaat Önderlerinin Okul yönetimine Katkıları", Uluslararası Insan Bilimleri Dergisi, 8 (2), $879-904$.

Longest, Jr. \& Beaufort, B. \& Darr, K. E. (1993). Organizational leadership in hospitals. Hospital Topics, 71 (3), 11-15.

Limanlılar M. (1991). Siyasal Pazarlama. Pazarlama Dünyası Dergisi, 39 (5), 29-39.

Mc Carty, E. J. (1975). Basic Marketing: A Management Approach (5th ed. ). Homewood, IL, United States of America: Richard D. Irwin Publishing.

Miller, William J. (2013). We Can't All Be Obama: The Use of New Media in Modern Political Campaigns, Journal of Political Marketing, 12 (4), 326-347. DOI: 10. 1080/15377857. 2013. 837312

Mucuk İ. (1999). Pazarlama İlkeleri, İstanbul: Türkmen Kitabevi.

Okumuş A. (2007). Pazarlama Anlayışında Siyasal Pazarlamanın Yeri Ve Pazar Konumlarına Göre Siyasal Partilerin Stratejik Analizi, 
Dumlupınar Üniversitesi, Sosyal Bilimler Dergisi, 17, 157-172.

Özkan N. (2004). Seçim Kazandıran Kampanyalar, İstanbul: Mediacat Yayınları.

Qualter, Terence H. (1985). Opinion Control in the Democracies. London: Palgrave Macmillian.

Rutherford, P. (2000). Endless Propaganda: The Advertising of Public Goods. Toronto: University of Toronto Press.

Towner, Terri L. \& Dulio, David A. (2012). New Media and Political Marketing in the United States: 2012 and Beyond, Journal of Political Marketing, 11 (1-2), 95-119, DOI: 10. 1080/15377857. 2012. 642748

Üste R. B. , Yüksel B. , Çalışkan S. (2007). 2007 Genel Seçimlerinde Siyasal Pazarlama Tekniklerinin Kullanımı ve İzmir Ili Örneği, SDÜ Fen Edebiyat Fakültesi Sosyal Bilimler Dergisi, 15, 213-232.

\section{Internet References}

http: /lihsanoglu. com/_(E. T. 17. 08. 2014).

https: //sonuc. ysk. gov. tr/module/GirisEkrani. jsf, (E. T. 15. 08. 2014).

http: //www. haberturk. com/secim/secim2014/cumhurbaskanligi-secimi, (E. T. 13. 08. 2014).

http: //www. rte. com. trl/, (E. T. 16. 08. 2014).

http: //www. selahattindemirtas. net/, (E. T. 17. 08. 2014).

http: //www. sozcu. com. tr/2014/gundem/iste-erdogana-yapilan-secim-bagisi-573957

http: //www. trtturk. com/haber/cumhurbaskani-adaylari-ne-kadar-bagis-topladi. html, (E. T. 27. 08. 2014).

Sabah (2012): "Facebook'ta Avrupa Lideriyiz", http: //www. sabah. com. tr/Teknoloji/Haber/2012/01/27/facebookta-avrupa-lideriyiz, (E. T. 25. 08. 2014).

Social media accounts of the candidates, both in Twitter and Facebook 